\title{
ESTIMASI KANDUNGAN KARBON ATAS PERMUKAAN TANAH PADA HUTAN ALAM DAN HUTAN REHABILITASI MANGROVE TAMAN HUTAN RAYA NGURAH RAI BALI
}

\author{
Made Suartana ${ }^{1 *)}$, I Nyoman Merit ${ }^{2)}$, I Made Sudarma ${ }^{3)}$ \\ ${ }^{1)}$ Balai Pengendalian Perubahan Iklim dan Kebakaran Hutan dan Lahan \\ Wilayah Jawa Bali Nusa Tenggara, \\ ${ }^{2)}$ Program Studi Magister Ilmu Lingkungan, Pascasarjana, Universitas Udayana \\ ${ }^{3)}$ Program Studi Doktor Ilmu Lingkungan, Pascasarjana, Universitas Udayana \\ *email: akumadesuartana@gmail.com
}

\section{ABSTRACT \\ ESTIMATION OF ABOVE GROUND CARBON IN NATURAL AND REHABILITATION MANGROVE AREA AT TAMAN HUTAN RAYA NGURAH RAI BALI}

\begin{abstract}
Mangroves are ecosystems that play an important role in absorbing and storing carbon from the air, one of which is in the form of mangrove vegetation biomass. As the largest mangrove area in Bali which consists of natural and rehabilitation vegetation, Taman Hutan Raya Ngurah Rai has a large potential for high carbon content. To determine the carbon potential of mangroves in natural and rehabilitation forests, a research was conducted using the purposive sampling method based on the canopy density level which was divided into 5 categories, namely very rare, rare, moderate, dense, very dense. Based on the results of measurements and calculations, the total carbon content of Ngurah Rai Grand Forest Park is 86.521,74 tons C, consisting of natural forest content $66.857,53$ tons $\mathrm{C}$ and rehabilitation forest 19.664,21 tons C. Above ground carbon per hectare in natural forest was not significantly different from the above ground carbon per hectare in rehabilitation forest, these results indicate that the carbon content per hectare of rehabilitation forest over 20 years old is almost close to the carbon content per hectare in natural forest. The diameter of trees and vegetation types did not significantly affect the carbon content of mangroves, these results indicate that the increase in carbon stocks in each type of vegetation in natural and rehabilitation forests is in line with diameter growth.
\end{abstract}

Keywords: Biomass; Density; Diameter; Canopy.

\section{PENDAHULUAN}

Keberadaan mangrove sangat penting dalam upaya mitigasi perubahan iklim. Perubahan iklim menjadi isu yang berkembang dengan cepat dan mempengaruhi kebijakan global dunia, tidak terkecuali di Indonesia. Modalitas Indonesia dengan mangrove tersebar hampir di seluruh wilayah, memiliki peran signifikan dalam upaya penanggulangan perubahan iklim lingkup nasional dan dunia. Hal tersebut karena kemampuan mangrove dalam penyerapan serta penyimpanan karbon.
Mangrove menyerap serta menyimpan karbon berupa biomassa atas serta bawah permukaan tanah. Menurut IPCC (2006), karbon atas mangrove adalah karbon yang berasal dari semua biomassa vegetasi hidup pada permukaan tanah, pohon serta kayu yang sudah mati termasuk serasah yang terdapat di permukaan tanah. Pada ekosistem mangrove, perhitungan cadangan karbon atas mangrove mengabaikan faktor serasah. Faktor serasah diabaikan karena pengaruh pasang surut yang mengakibatkan keberadaan serasah selalu berubah setiap saat.

Taman Hutan Raya Ngurah Rai merupakan wilayah dengan hutan mangrove terbesar di Pulau Bali, dengan luas kawasan \pm 
1.373,5 Ha, dimana dari luasan tersebut yang bertutupan vegetasi seluas 1.002,22 ha terdiri atas hutan alam dengan luas 725,36 , hutan rehabilitasi seluas 276,86 ha (Pratama et.al., 2019). Hutan alam merupakan hutan dengan vegetasi yang pertumbuhannya mencapai klimaks, tanpa ataupun sedikit mendapatkan campur tangan oleh manusia (Arief, 2001). Sonneratia alba merupakan jenis yang paling banyak ditemukan di hutan alam Tahuran Ngurah Rai. Masih menurut Arief (2001), hutan rehabilitasi didefinisikan sebagai hutan yang vegetasinya tumbuh melalui penanaman pohon yang dilakukan oleh manusia. Hutan rehabilitasi Tahura Ngurah Rai didominasi oleh Rhizophoraceae (Rhizopora mucronata, $R$. stylosa, R. apiculata).

Sebagai kawasan mangrove terluas di Bali dengan kondisi vegetasi yang cukup baik, Tahura Ngurah Rai menyimpan potensi yang cukup besar dalam penyerapan karbon, termasuk karbon atas mangrove. Sampai dengan saat ini informasi tentang simpanan karbon atas mangrove Tahura Ngurah Rai masih sangat terbatas. Untuk itu dipandang perlu melakukan penelitian kandungan karbon atas mangrove Tahura Ngurah Rai pada kedua tipe vegetasi (hutan alam dan hutan rehabilitasi).

Tujuan penelitian untuk menganalisis simpanan karbon atas permukaa $\mathrm{n}$ tanah serta menganalisis hubungan antara ukuran diameter dan jenis pohon dengan kemampuan menyimpan karbon pada hutan alam rehabilitasi Tahura Ngurah Rai, Bali.

\section{METODOLOGI}

Penelitian estimasi kandungan karbon atas mangrove pada hutan alam dan hutan rehabilitasi Tahura Ngurah Rai merupakan penelitian kuantitatif. Penelitian diawali dengan mengumpulkan data luasan hutan mangrove Tahura Ngurah Rai berdasarkan tipe vegetasi (hutan alam dan rehabilitasi) serta data kerapatan tajuk mangrove serta sebarannya.

Pengukuran sampel guna mengetahui simpanan karbon atas pada hutan mangrove ditujukan pada vegetasi mangrove yang masih hidup, vegetasi yang mati baik yang berdiri atau sudah roboh dengan diameter $\geq 5 \mathrm{~cm}$ (Komiyama et al., 2005). Metode yang dipakai berupa Purposive Sampling berdasarkan stratifikasi tingkat kerapatan tajuk (sangat.jarang,.jarang,.sedang,.rapat, .sangat rapat). Stratifikasi tingkat kerapatan tajuk merujuk pada penelitian Pratama et al. (2019) tentang distribusi atau sebaran spasial kerapatan tajuk mangrove berdasarkan Citra Sentinel-2A pada Taman Hutan Raya Ngurah Rai.

Plot sampel dibuat pada tiap tipe hutan (hutan alam dan hutan rehabilitasi) dan tingkat kerapatan tajuk dan diulang masing-masing sebanyak 3 (tiga) kali sehingga plot sampel berjumlah 30 plot. Plot sampel berbentuk persegi dengan panjang sisi $10 \mathrm{~m}$. Kegiatan selanjutnya berupa pengukuran lapangan sesuai dengan plot sampel yang telah ditentukan, dilanjutkan dengan penghitungan biomassa dengan persamaan allometrik sesuai jenis mangrove serta menghitung estimasi kandungan karbon atas permukaan tanah. Adapun instrumen yang digunakan pada penelitian selengkapnya terlampir (Tabel 1.) Peta yang menunjukkan tempat penelitian selengkapnya terlampir (Gambar 1.)

Penelitian dilaksanakan pada Januari Mei 2021. Pengambilan data di lapangan dilakukan pada bulan Januari - Maret 2021 sedangkan pengolahan data dilakukan pada bulan April - Mei 2021. 
Tabel 1. Instrumen Penelitian

\begin{tabular}{cll}
\hline No & \multicolumn{1}{c}{ Instrumen } & \multicolumn{1}{c}{ Kegunaan } \\
\hline 1 & GPS & Menentukan koordinat \\
2 & Phi band/pita meter & Mengukur diameter/keliling \\
3 & Pita meter/rol meter & Mengukur panjang \\
4 & Kompas & Mengukur azimuth/sudut \\
5 & Peta Kerja & Menentukan lokasi plot \\
6 & Aplikasi "Tides" & Mengetahui pasang surut \\
7 & Parang & Membuat rintisan \\
8 & Tally sheet & Mencatat data \\
9 & Alat tulis & Untuk menulis \\
10 & Kamera & Dokumentasi \\
\hline
\end{tabular}

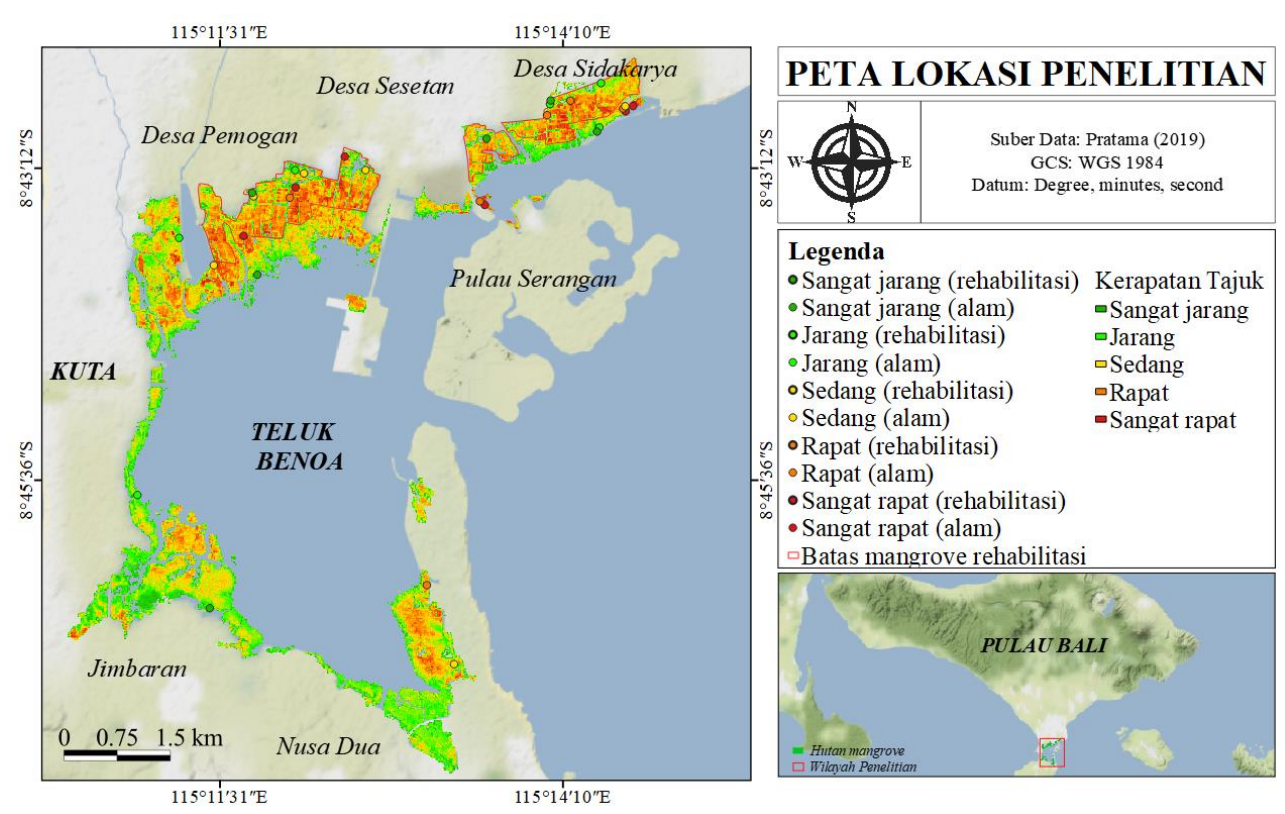

Gambar 1.

Peta Penelitian (Sumber : Pratama et al., 2019)

\subsection{Penentuan Titik dan Pembuatan Plot Sampel}

Penentuan titik dan pembuatan plot sampel dilaksanakan pada tiap tipe vegetasi (hutan alam dan hutan rehabilitasi) dan tingkat kerapatan tajuk (sangat jarang, jarang, sedang, rapat, sangat rapat) dengan mempertimbangkan aksesbilitas. Plot pada masing-masing tingkat kerapatan tajuk (5 tingkat kerapatan) diulang masing-masing sebanyak 3 (tiga) kali sehingga jumlah plot sampel pengamatan sebanyak 30 plot (2 tipe vegetasi, 5 tingkat kerapatan tajuk, 3 kali ulangan). Plot sampel berbentuk persegi dengan ukuran plot sebesar $10 \times 10 \mathrm{~m}$ (Komiyama et al., 2005).

\subsection{Pengukuran Diameter dan Identifikasi Jenis}

Pengukuran diameter dilakukan terhadap tegakan yang terdapat dalam plot, baik berupa pohon yang masih hidup, pohon yang mati dan kayu mati serta dicatat jenisnya. Pengukuran diameter dilakukan pada vegetasi mangrove baik pohon hidup dan pohon mati dengan kondisi tetap berdiri atau telah roboh dengan diameter $\geq 5 \mathrm{~cm}$ (Komiyama et al., 2005).

Pengukuran diameter dilakukan setinggi dada untuk menghitung dimensi suatu pohon dengan tinggi $1,3 \mathrm{~m}$ di atas permukaan tanah mengikuti ketentuan berdasarkan teknis pengukuran menurut Asy'ari (2012), sebagai berikut (Gambar 2.) 


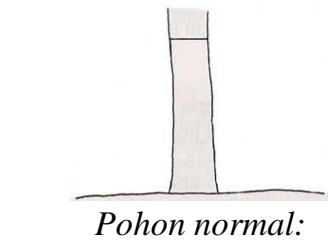

Ukur pada ketinggian 1,3 m

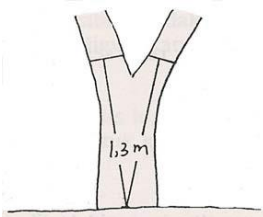

Pohon bercabang:

Jika percabangan di bawah 1,3 meter, diameter di ukur setinggi 1,3 meter (jumlah pohon dihitung sesuai jumlah cabang)

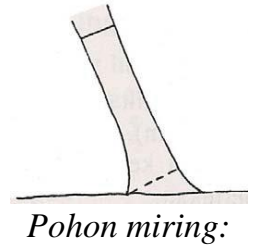

Ukur pada ketinggian 1,3 m mengikuti sudut kemiringan

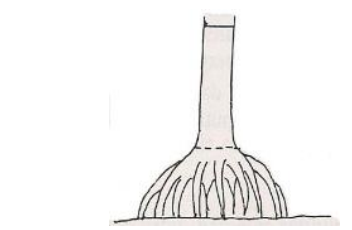

Pohon dengan akar tunjang:

Diameter diukur 1,3 meter di atas akar tunjang
Pohon bercabang:

Jika percabangan di atas $1,3 \mathrm{~m}$, diameter diukur di bawah percabangan (dihitung 1 pohon)

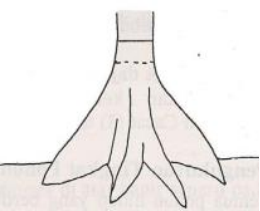

Pohon dengan akar banir: Pengukuran diameter dilakukan $20 \mathrm{~cm}$ di atas banir

Gambar 2.

Teknis Pengukuran Diameter Setinggi Dada (Asy’ari, 2012)

Identifikasi jenis mangrove dilakukan berpedoman pada Handbook of Mangroves in Indonesia; Bali \& Lombok (Kitamura et al., 1997).

\subsection{Penghitungan Biomassa}

Penghitungan biomassa dilakukan pada pohon hidup, pohon mati dan kayu mati. Prosedur penghitungan biomassa pada masingmasing kondisi pohon sebagai berikut:

\subsubsection{Penghitungan.Biomassa Pohon Menggunakan Persamaan Allometrik}

Tahapan penghitungan menggunakan persamaan allometrik sebagai berikut:

a. Ukur diameter pohon;

b. Identifikasi jenis pohon ;

c. Hitung biomassa pohon dengan persamaan allometrik sesuai jenis yang teridentifikasi.

Persamaan allometrik untuk beberapa jenis mangrove yang dirujuk dalam penelitian selengkapnya terlampir (Tabel 2.)

Tabel 2. Model Allometrik Karbon Atas Permukaan Jenis Mangrove Teridentifikasi pada Plot Sampel

\begin{tabular}{lll}
\hline \multicolumn{1}{c}{ Jenis species } & \multicolumn{1}{c}{ Model Allometrik } & \multicolumn{1}{c}{ Sumber } \\
\hline Rhizophora apiculata & $\mathrm{B}=0,043 * \mathrm{D}^{2,63}$ & Amira, 2008 \\
Rhizophora mucronata & $\mathrm{B}=0,1466 * \mathrm{D}^{2,3136}$ & Dharmawan, 2013 \\
Rhizophora stylosa & $\mathrm{B}=0,1579 * \mathrm{D}^{2,593}$ & Analuddin et al., 2020 \\
Sonneratia alba & $\mathrm{B}=0,3841 * \rho \mathrm{D}^{2,101}$ & Kauffman dan Cole, 2010 \\
Bruguiera gymnorrhiza & $\mathrm{B}=\rho * 0,0754 * \mathrm{D}^{2,505}$ & Kauffman et al., 2012 \\
\hline
\end{tabular}

\subsubsection{Penghitungan Biomassa pada Pohon Mati Menggunakan Persamaan Allometrik}

Tahap penghitungan

pada pohon mati menggunakan persamaan allometrik adalah:

a. Mengukur diameter pohon mati.

b. Identifikasi jenis mangrove. c. Menentukan derajat keutuhan pada pohon mati yang berpedoman pada Gambar 3.

d. Menghitung biomassa pohon yang mati (mengalikan derajat keutuhan pohon dengan persamaan allometrik sesuai jenis pohon). 


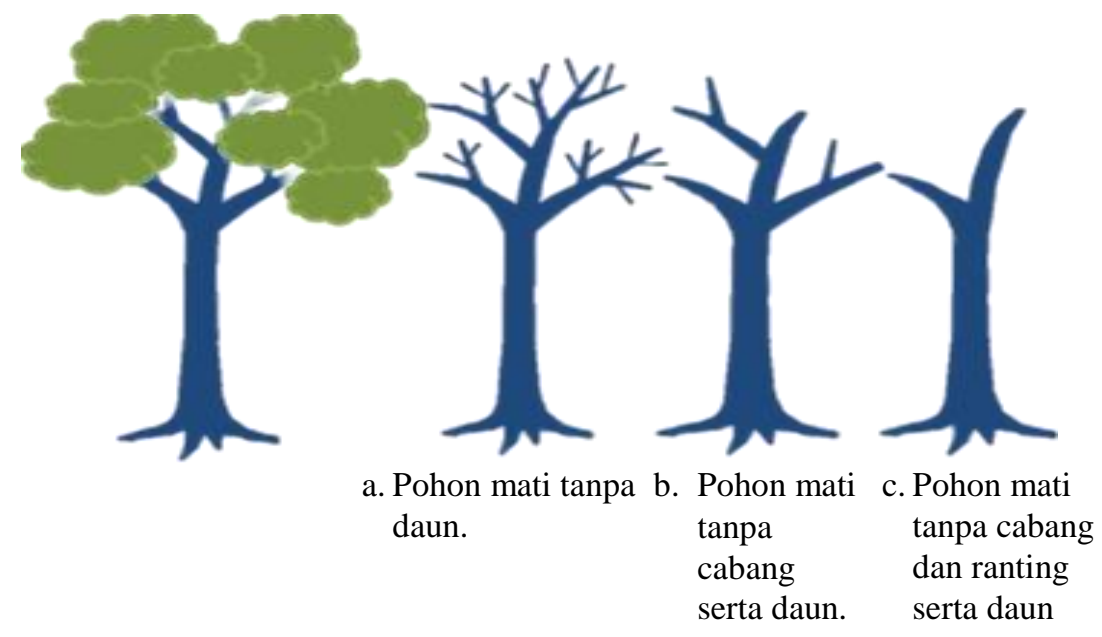

Gambar 3.

Derajat Keutuhan Pohon Mati

Keterangan gambar :

a : Derajat keutuhan nilai 0,9 (faktor koreksi)

b : Derajat keutuhan nilai 0,8 (faktor koreksi)

c : Derajat keutuhan nilai 0,7 (faktor koreksi)

\subsubsection{Penghitungan Biomassa Kayu yang Mati dengan Menghitung Volume}

Untuk menghitung biomassa kayu yang mati melalui penghitungan volume kayu dilakukan dengan tahapan sebagai berikut:

a.Mengukur diameter pangkal dan diameter ujung.

b.Mengukur panjang kayu.

c.Menghitung volume dengan rumus Bre reton.

$$
V k m=0,25 \pi\left(\frac{d p+d u}{2 \times 100}\right)^{2} X P
$$

Keterangan :

$V k m$ : Volume kayu mati $\left(\mathrm{m}^{3}\right)$.

$d p \quad: \quad$ Diameter pangkal $(\mathrm{cm})$.

$d u \quad$ : Diameter ujung $(\mathrm{cm})$.

$p \quad$ : Panjang kayu (m).

$\pi \quad$ : $\quad 3,14$ atau 22/7

d.Menghitung biomassa kayu (Rumus

Badan Standardisasi Nasional, 2011).

$$
B k m=V k m \times B J k m
$$

Keterangan :

$B k m$ : Biomassa kayu mati $(\mathrm{kg})$.

$V k m$ : Volume kayu mati (m3).

$B J k m$ : Berat jenis kayu mati $(\mathrm{kg} / \mathrm{m} 3)$.

\subsubsection{Penghitungan Karbon dari Biomassa}

Penghitungan karbon dilakukan dengan cara mengalikan nilai biomassa dengan nilai $\mathrm{C}$ organik dengan rumus sesuai Badan Standarisasi Nasional (2011);

$$
C b=B x \% \text { C organik }
$$

Keterangan :

$\mathrm{Cb}$

$\mathrm{B}$

$\% \mathrm{C}$ organik : Nilai persentase karbon $(0,47)$

Catatan : Penghitungan karbon dilakukan pada kandungan karbon biomassa atas pohon (C bap), karbon pohon mati $(\mathrm{C}$ pm) dan karbon kayu mati $(\mathrm{C} \mathrm{km})$.

\subsubsection{Penghitungan Kandungan Karbon per Hektar}

Kandungan karbon per hektar di atas permukaan tanah penghitungannya mengacu mengacu persamaan Badan Standardisasi Nasional (2011) sebagai berikut:

$$
C n=\frac{C x}{1.000} \times \frac{10.000}{\text { lplot }}
$$


Keterangan :

Cn : Kandungan karbon per hektar pa da carbon pool pada tiap plot (ton/ha).

Cx : Kandungan karbon pada tiap car bon pool pada tiap plot $(\mathrm{kg})$.

1 plot : Luas plot sampel (m2).

\subsubsection{Penghitungan Total Karbon di atas Permukaan Tanah}

Total kandungan karbon Tahura Ngurah Rai yang tersimpan pada permukaan tanah dapat diketahui dengan penghitungan yang mengacu rumus Badan Standardisasi Nasional (2011):

$C$ total apt $=C$ bap $+C \mathrm{~km}+C \mathrm{pm}$

Keterangan:

C total apt : Total karbon atas permukaan tanah (ton).

C bap : Kandungan karbon biomassa a tas permukaan per hektar (ton/ha).

C km : Kandungan karbon kayu mati per hektar (ton/ha).

$\mathrm{C}$ pm : Kandungan karbon pohon mati per hektar (ton/ha).

\subsubsection{Analisis data}

Data hasil penelitian di analisis secara statistik dengan program SPSS. Untuk uji hipotesis tujuan (1) apakah ada perbedaan simpanan karbon atas permukaan tanah pada hutan alam dan rehabilitasi mangrove Tahura Ngurah Rai, akan dilakukan analisis Independent Samples T-Test.

Persamaan uji T 2 sampel independen sebagai berikut :

$$
t=\frac{\overline{\mathrm{x}}_{2}-\overline{\mathrm{x}}_{1}}{S p \sqrt{\frac{1}{n 1}+\frac{1}{n 2}}}
$$

Keterangan :

$\mathrm{t}$ : nilai statistik $\mathrm{t}$

$\overline{\mathrm{x}}_{2}$ : rata-rata sampel 2 (karbon hutan rehabilitasi)

$\overline{\mathrm{x}}_{1}$ : rata-rata sampel 1 (karbon hutan alam)

Sp : standar deviasi gabungan

n1 : Jumlah sampel hutan alam n2 : Jumlah sampel hutan rehabilitasi

di mana SP merupakan standar deviasi gabungan untuk 2 (dua) sampel yang dihitung dengan rumus:

$$
S p=\sqrt{\frac{S 1^{2}(n 1-1)+S 2^{2}(n 2-1)}{n 1+n 2-2}}
$$

Keterangan :

$$
\begin{array}{lll}
\mathrm{Sp} & : & \text { nilai statistik t } \\
S 1 & : & \begin{array}{l}
\text { rata-rata sampel 2 } \\
\text { (karbon hutan }
\end{array} \\
& & \begin{array}{l}
\text { rehabilitasi) } \\
\text { rata-rata sampel 1 } \\
\text { (karbon hutan alam) }
\end{array} \\
S 2 & : & \begin{array}{l}
\text { Jumlah sampel hutan } \\
\text { alam }
\end{array} \\
\mathrm{n} 1 & : & \begin{array}{l}
\text { Jumlah sampel hutan } \\
\text { rehabilitasi }
\end{array} \\
\mathrm{n} 2 & : & \text { Derajat bebas }
\end{array}
$$

Untuk uji hipotesis tujuan (2) apakah ada hubungan diameter dan jenis pohon terhadap kandungan karbon yang tersimpan pada permukaan tanah di hutan alam dan rehabilitasi Tahura Ngurah Rai, akan dilakukan analisis regresi linear berganda dengan dummy. Analisis regresi linear berganda dengan dummy digunakan karena salah satu variabel bebas berupa jenis pohon merupakan data kualitaif, sehingga variabel jenis pohon akan di ubah menjadi variabel kuantitatif.

$Y^{\prime}=a+b X+c D$

Keterangan:

$$
\begin{array}{lll}
\mathrm{Y}^{\prime} & : & \text { Jumlah simpanan karbon atas } \\
& & \text { permukaan tanah }\left(\text { ton } \mathrm{ha}^{-1}\right) \\
\mathrm{X} & : & \text { Diameter pohon }(\mathrm{m}) \\
\mathrm{D} & : & \text { Jenis vegetasi }(1=\text { vegetasi } \\
& & \text { dominan, } 0=\text { vegetasi lainnya) } \\
\mathrm{a} & : & \text { Konstanta } \\
\mathrm{b} & : & \text { Koefisien regresi } \\
\mathrm{c} & : & \text { Koefisien dummy }
\end{array}
$$

\section{HASIL DAN PEMBAHASAN}

\subsection{Kandungan Biomassa Atas Permukaan Tanah Hutan Alam Tahura Ngurah Rai}

Kandungan biomassa pada hutan alam mangrove Tahura Ngurah Rai diperoleh dari penjumlahan biomassa pohon hidup, pohon 
Estimasi Kandungan Karbon Atas Permukaan Tanah...

mati dan biomassa kayu yang sudah mati. Biomassa pohon dihitung dengan menggunakan persamaan allometrik untuk vegetasi mangrove (Tabel 2.). Melalui model allometrik, biomassa pohon dapat di hitung dengan memasukkan satu parameter atau kombinasi beberapa parameter berupa diameter, berat jenis dan tinggi. Biomassa pohon mati dihitung dengan metode yang sama (model allometrik) dikalikan dengan derajat keutuhan pohon yang merupakan faktor koreksi dengan nilai 0,7 sampai dengan 0,9 sesuai Gambar 2. Sedangkan untuk kayu mati biomassa dihitung dengan mengalikan hasil penghitungan volume kayu yang mati dengan berat jenis kayu sesuai jenisnya.

Rata-rata kandungan biomassa per hektar pada tiap tingkat kerapatan tajuk pada hutan alam Tahura Ngurah Rai disajikan pada Gambar 4.

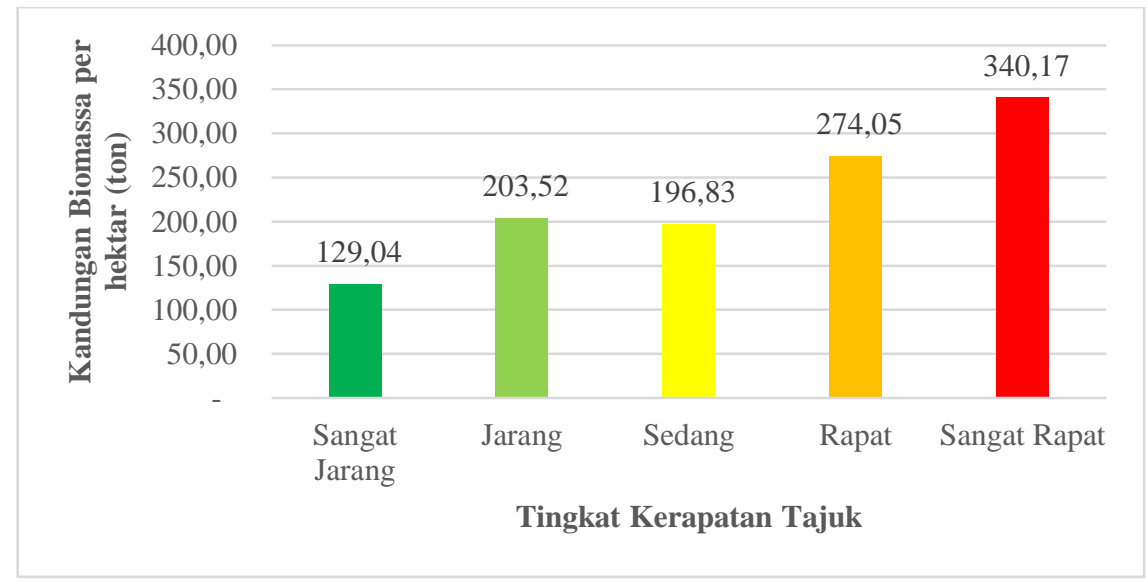

Gambar 4.

Histogram Kandungan Biomassa rata-rata per hektar pada tiap Tingkat Kerapatan Tajuk pada Hutan Alam Tahura Ngurah Rai

\subsection{Kandungan Karbon Atas Permukaan Tanah Hutan Alam Tahura Ngurah Rai}

Kandungan karbon pada hutan alam mangrove Tahura Ngurah Rai diperoleh dengan cara mengalikan kandungan biomassa dengan 0,47 yang merupakan angka persentase nilai karbon pada suatu tegakan. Rata-rata kandungan karbon per hektar pada tiap tingkat kerapatan tajuk pada hutan alam Tahura Ngurah Rai disajikan pada Gambar 5.

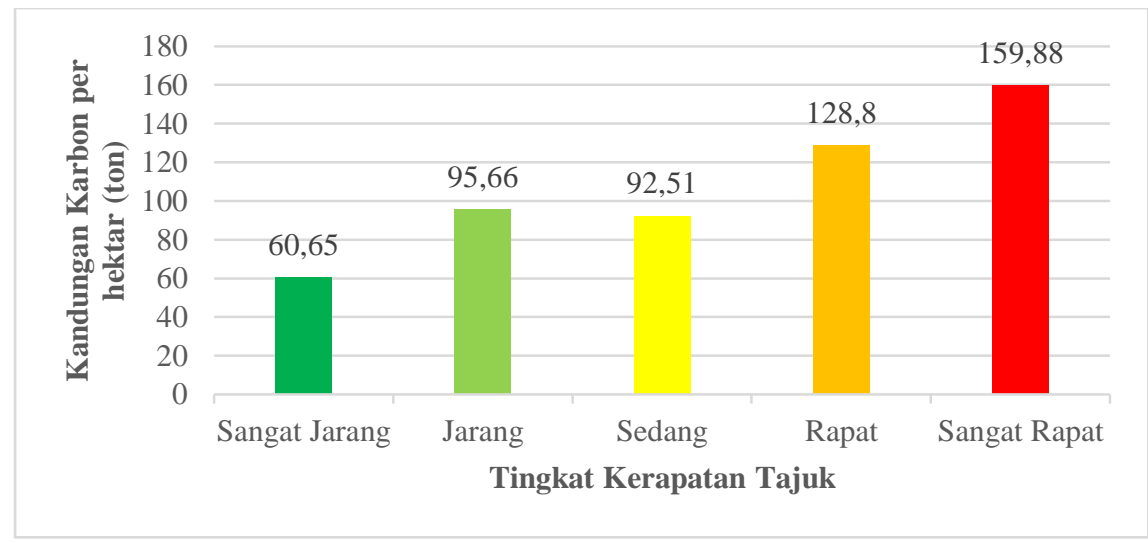

Gambar 5.

Histogram Kandungan Karbon rata-rata per hektar pada tiap Tingkat Kerapatan Tajuk pada Hutan Alam Tahura Ngurah Rai

Total karbon pada permukaan tanah di hutan alam Tahura Ngurah Rai diperoleh dengan cara mengalikan nilai rata-rata kandungan karbon per hektar pada tiap tingkat kerapatan tajuk dengan luas masing-masing tingkat kerapatan tajuk. Luas areal dengan 
tingkat kerapatan tajuk sangat jarang seluas 146,08 ha, jarang 344,11 ha, sedang 206,55 ha, rapat 43,85 ha dan sangat rapat 2,03 ha. Kandungan karbon total berdasarkan hasil akumulasi kandungan karbon pada tiap tingkat kerapatan pada hutan alam Tahura Ngurah adalah $66.857,53$ ton $\mathrm{C}$.

\subsection{Kandungan \\ Biomassa \\ Atas Permukaan Tanah Hutan Rehabilitasi Tahura Ngurah Rai}

Mekanisme penghitungan biomassa pada hutan rehabilitasi sama dengan penghitungan pada hutan alam. Berdasarkan hasil penghitungan, rata-rata kandungan biomassa per hektar pada tiap tingkat kerapatan tajuk pada hutan rehabilitasi Tahura Ngurah Rai disajikan pada Gambar 6.

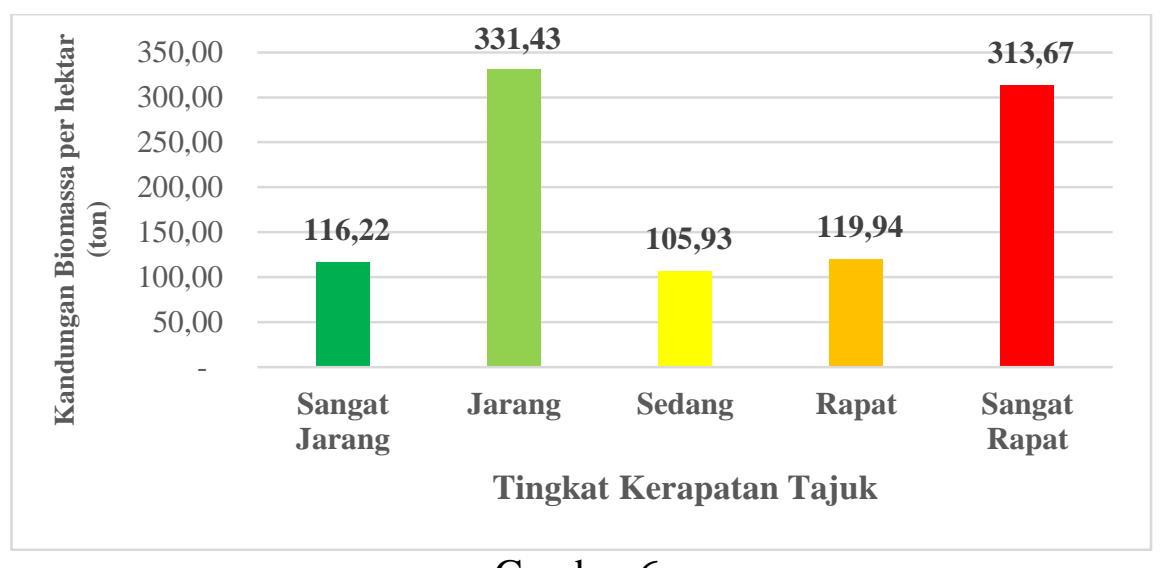

Gambar 6.

Histogram Kandungan Biomassa rata-rata per hektar pada tiap Tingkat Kerapatan Tajuk pada Hutan Rehabilitasi Tahura Ngurah Rai

\subsection{Kandungan Karbon Atas Permukaan Tanah Hutan Rehabilitasi Tahura Ngurah Rai}

Kandungan karbon pada hutan rehabilitasi mangrove Tahura Ngurah Rai diperoleh dengan cara mengalikan kandungan biomassa dengan 0,47 yang merupakan angka persentase nilai karbon pada suatu tegakan. Rata-rata kandungan karbon per hektar pada tiap tingkat kerapatan tajuk pada hutan rehabilitasi Tahura Ngurah Rai disajikan pada Gambar 6.

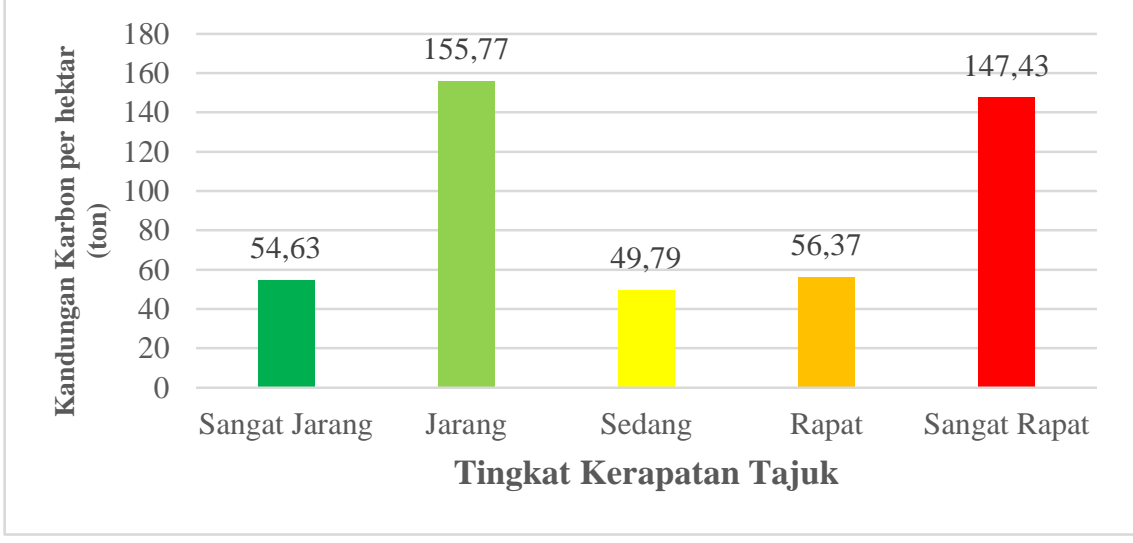

Gambar 6.

Histogram Rata-rata Kandungan Karbon per hektar pada tiap Tingkat Kerapatan Tajuk pada Hutan Rehabilitasi Tahura Ngurah Rai

Total kandungan karbon atas permukaan tanah pada hutan rehabilitasi mangrove Tahura Ngurah Rai diperoleh dengan cara mengalikan nilai rata-rata kandungan karbon per hektar pada tiap tingkat kerapatan tajuk dengan luas masing-masing tingkat kerapatan tajuk. Luas 
areal dengan tingkat kerapatan tajuk sangat jarang seluas 22,70 ha, jarang 58,27 ha, sedang 126,45 ha, rapat 50,97 ha dan sangat rapat 1,21 ha. Total kandungan karbon atas permukaan tanah pada hutan rehabilitasi Tahura Ngurah Rai sebesar 19.664,21 ton C.

\subsection{Total Kandungan Karbon di Atas Permukaan Tanah Tahura Ngurah Rai}

Total kandungan karbon atas permukaan tanah Tahura Ngurah Rai merupakan akumulasi dari total kandungan karbon atas pada hutan alam dan hutan rehabilitasi. Berdasarkan hasil penghitungan, total kandungan karbon atas permukaan tanah pada hutan alam Tahura Ngurah Rai sebesar $66.857,53$ ton dan hutan rehabilitasi Tahura Ngurah Rai sebesar 19.664,21 ton, sehingga total kandungan karbon atas permukaan tanah di Tahura Ngurah Rai adalah sebesar $86.521,74$ ton. Total simpanan karbon atas permukaan tanah Tahura Ngurah Rai disajikan pada Gambar 7.

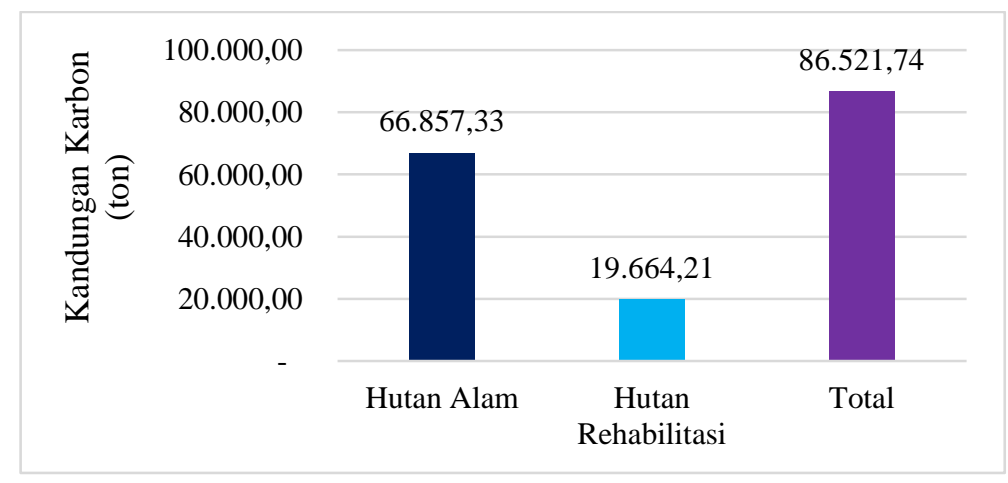

Gambar 7.

Histogram Total Simpanan Karbon Atas Permukaan Tanah Tahura Ngurah Rai

3.6. Hubungan antara Ukuran Diameter Pohon terhadap Simpanan Karbon Atas Permukaan Tanah pada Hutan Alam Tahura Ngurah Rai

Berdasarkan hasil penghitungan karbon atas mangrove pada hutan alam dapat diketahui hubungan antara ukuran diameter pohon terhadap simpanan karbon atas permukaan tanah. Rata-rata diameter dan kandungan karbon per hektar pada tiap tingkat kerapatan tajuk pada hutan alam Tahura Ngurah Rai disajikan pada Gambar 8.

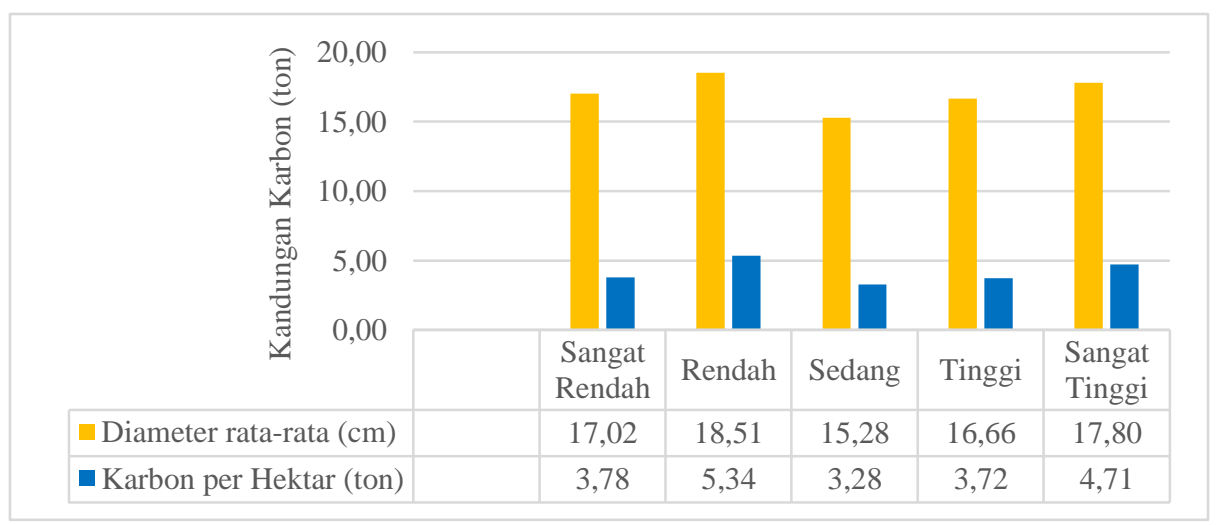

Gambar 8 .

Histogram Diameter rata-rata dan Kandungan Karbon per hektar pada tiap Tingkat Kerapatan Tajuk pada Hutan Alam Tahura Ngurah Rai

Berdasarkan Gambar 8., kandungan dengan jenis dominan yang merupakan kabon atas per ha terendah sebesar 3,28 ton C kombinasi Sonneratia alba dengan $\mathrm{ha}^{-1}$ terdapat pada tingkat kerapatan tajuk Rhizophora mucronata dan Rhizophora sedang dengan rata-rata diameter $15,28 \mathrm{~cm}$ apiculata. Sedangkan kandungan karbon atas 
per hektar tertinggi sebesar 5,34 ton $\mathrm{C} \mathrm{ha}^{-1}$ terdapat pada tingkat kerapatan tajuk rendah/jarang dengan rata-rata diameter 18,51 $\mathrm{cm}$ dengan jenis dominan Sonneratia alba dan Rhizophora stylosa. Berdasarkan data tersebut ukuran diameter berbanding lurus dengan kandungan karbon yang berarti bahwa peningkatan diameter akan meningkatkan kandungan karbon.
3.7. Hubungan antara Ukuran Diameter Pohon terhadap Simpanan Karbon Atas Permukaan Tanah pada Hutan Rehabilitasi Tahura Ngurah Rai

Berdasarkan hasil penghitungan karbon atas mangrove pada hutan rehabilitasi dapat diketahui hubungan antara ukuran diameter pohon terhadap simpanan karbon atas permukaan tanah. Rata-rata diameter dan kandungan karbon per hektar pada tiap tingkat kerapatan tajuk pada hutan rehabilitasi Tahura Ngurah Rai disajikan pada Gambar 9.

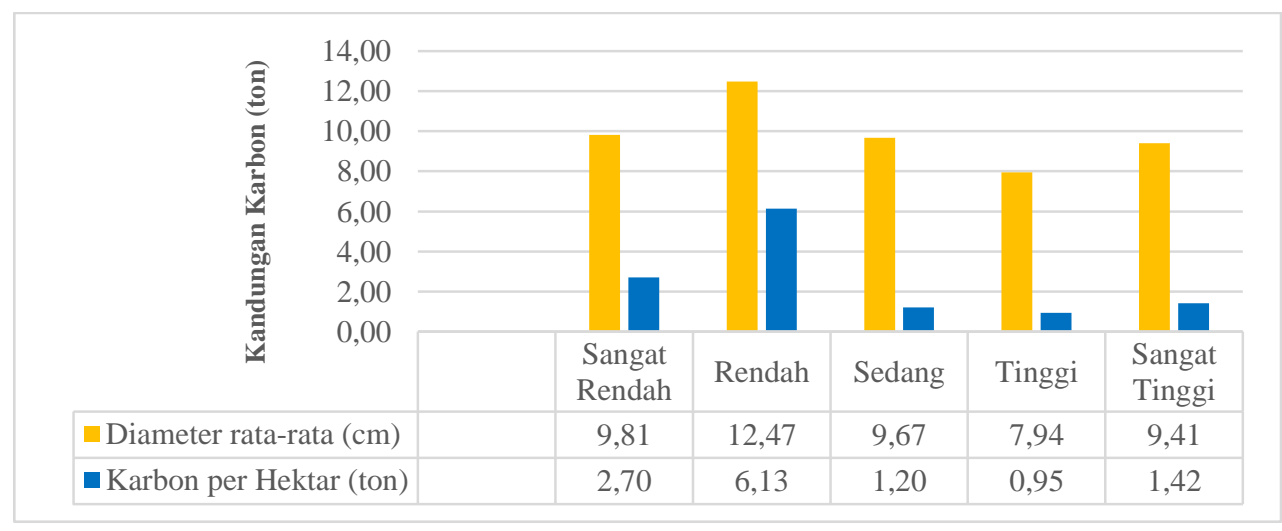

Gambar 9.

Histogram Diameter rata-rata dan Kandungan Karbon per hektar pada tiap Tingkat Kerapatan Tajuk pada Hutan Rehabilitasi Tahura Ngurah Rai

Berdasarkan Gambar 9., kandungan karbon atas per hektar terendah sebesar 0,95 ton $\mathrm{C} \mathrm{ha}{ }^{-1}$ terdapat pada tingkat kerapatan tajuk rapat/tinggi dengan rata-rata diameter $7,94 \mathrm{~cm}$ dengan jenis dominan adalah Rhizophora stylosa dan Rhizophora apiculata. Sedangkan kandungan karbon atas per hektar tertinggi sebesar 6,13 ton $\mathrm{C} \mathrm{ha}^{-1}$ terdapat pada tingkat kerapatan tajuk rendah/jarang dengan rata-rata diameter $12,47 \mathrm{~cm}$ dengan jenis dominan Rhizophora stylosa. Sama halnya dengan di hutan alam, ukuran diameter berbanding lurus dengan kandungan karbon. yang bermakna bahwa peningkatan diameter akan menyebabkan peningkatan kandungan karbon. Berdasarkan data rata-rata kandungan karbon atas per hektar pada hutan alam maupun hutan rehabilitasi bahwa kandungan karbon tertinggi terdapat pada plot dengan tutupan tajuk jarang/rendah, dimana pada plot ini rata-rata diameter pohon paling besar.

\subsection{Kandungan Karbon Atas Permukaan Tanah}

Berdasarkan hasil uji statistik terhadap simpanan karbon atas Tahura Ngurah Rai didapatkan hasil sesuai Tabel 5.

Sesuai output seperti Tabel 5., diperoleh nilai signifikansi $0,076>0,05$ sehingga bermakna bahwa.varians.data.rata-rata kandungan karbon atas pada hutan alam dengan rata-rata kandungan karbon atas pada hutan rehabilitasi dinyatakan homogen. Dengan demikian penafsiran tabel output Independent Samples Test pada Tabel 5. berdasarkan nilai pada bagian "Equal variances assumed".

Sesuai output "Independent Samples Test" pada "Equal variances assumed" nilai.signifikansi $0,529>0,05$ sehingga bermakna tidak.terdapat.perbedaan yang nyata.pada rata-rata.kandungan karbon atas di.hutan alam dengan.rata-rata kandungan karbon atas hutan rehabilitasi. 
Tidak adanya perbedaan yang signifikan pada kandungan karbon atas per hektar pada hutan alam dan hutan rehabilitasi mangrove Tahura Ngurah Rai mengindikasikan bahwa kondisi vegetasi pada hutan rehabilitasi mangrove sudah hampir sama dengan kondisi vegetasi pada hutan alam. Hal ini berdampak pada kandungan biomassa dan karbon per hektar pada hutan rehabilitasi dan hutan alam tidak berbeda signifikan.

Berdasarkan hasil pengukuran dan penghitungan, kandungan karbon pada hutan alam sebesar 90,03 ton/ha sedangkan karbon pada hutan rehabilitasi 75,75 ton/ha. Kandungan karbon per hektar di Tahura Ngurah Rai lebih besar apabila dibandingkan dengan penelitian oleh Putra et al. (2019) yang menyatakan bahwa kandungan karbon pada hutan mangrove sebesar 15,71 ton/ha, penelitian Handoko (2016) di kawasan Selatan Pulau Rupat yang menyatakan bahwa cadangan karbon mangrove sebesar 58,8 ton/ha dan penelitian Sofyan (2016) di kawasan Pesisir Rupat Utara yang menyatakan rata-rata karbon mangrove sebesar 68,64 ton/ha. Akan tetapi kandungan karbon Tahura Ngurah Rai lebih kecil dibandingkan dengan kandungan karbon di kawasan mangrove Bahowo, Kelurahan Tongkaina, Kecamatan Bunaken yang sebesar 203,83 ton ton/ha (Bachmid et al., 2018). Penelitian Massugito (2016) yang menyatakan bahwa cadangan karbon mangrove di kawasan Pesisir Kuala Indragiri rata-rata sebesar 258,03 ton/ha dan penelitian Oktaviona et.al, (2017) di hutan mangrove Jorong Ujuang Labuang Sumatera Barat yang menyatakan kandungan karbon sebesar 1.333,99 ton ton/ha.

Tabel 5. Output Independent Samples Test Kandungan Karbon Atas Permukaan Tanah pada Hutan Alam dan Rehabilitasi Tahura Ngurah Rai

Independent.Samples.Test

\begin{tabular}{|c|c|c|c|c|c|c|c|c|c|c|}
\hline & \multicolumn{2}{|c|}{$\begin{array}{l}\text { Levene's.Test.for } \\
\text { Equality.of. } \\
\text { Variances. }\end{array}$} & \multicolumn{7}{|c|}{ t-test for Equality of Means } \\
\hline & & \multirow[b]{2}{*}{$\mathrm{F}$} & \multirow[b]{2}{*}{ Sig.. } & \multirow[b]{2}{*}{ t. } & \multirow[b]{2}{*}{ df. } & \multirow{2}{*}{$\begin{array}{c}\text { Sig. . } \\
\text {. (2-tailed) }\end{array}$} & \multirow{2}{*}{$\begin{array}{c}\text { Mean. } \\
\text { Difference }\end{array}$} & \multirow{2}{*}{$\begin{array}{l}\text { Std. .Error. } \\
\text { Difference }\end{array}$} & \multicolumn{2}{|c|}{$\begin{array}{c}\text { 95\%.Confidence.In } \\
\text { terval } \\
\text { of.the.Difference }\end{array}$} \\
\hline & & & & & & & & & Lower. & Upper. \\
\hline $\begin{array}{l}\text { Kandungan } \\
\text { Karbon }\end{array}$ & $\begin{array}{l}\text { Equal.variances. } \\
\text { assumed } \\
\text { Equal.variances. } \\
\text { not assumed }\end{array}$ & 3.395 & .076 & .638 & 23.728 & $\begin{array}{l}.529 \\
.530\end{array}$ & $\begin{array}{l}14.70067 \\
14.70067\end{array}$ & $\begin{array}{l}23.03794 \\
23.03794\end{array}$ & \begin{tabular}{|r|}
32.4904 \\
1 \\
- \\
32.8761 \\
5
\end{tabular} & $\begin{array}{r}61.8917 \\
4 \\
4 \\
62.2774 \\
8\end{array}$ \\
\hline
\end{tabular}

3.9. Hubungan antara Ukuran Diameter dan Jenis Pohon dengan Kandungan Karbon Atas Permukaan Tanah di Hutan Alam

Untuk mengetahui apakah diameter dan jenis pohon berpengaruh terhadap simpanan karbon atas pada hutan alam Tahura Ngurah Rai, dilakukan analisis terhadap output uji statistik seperti pada Tabel 6.

Berdasarkan Tabel 6., diperoleh nilai signifikansi untuk rata-rata diameter sebesar 0,181 atau lebih tinggi (>) 0,05 yang bermakna bahwa diameter tidak memberikan pengaruh nyata terhadap simpanan karbon atas di hutan alam Tahura Ngurah Rai. Untuk nilai signifikansi jenis dominan sebesar 0,209 atau lebih tinggi (>) 0,05 yang bermakna bahwa jenis pohon tidak memberikan pengaruh nyata terhadap simpanan karbon atas di hutan alam Tahura Ngurah Rai.

Karena 2 (dua) variabel bebas yang diuji terhadap simpanan karbon atas di hutan alam tidak memberikan pengaruh nyata, maka persamaan regresi linear diabaikan. Ukuran diameter yang tidak berpengaruh signifikan terhadap kandungan karbon pada hutan alam diduga disebabkan karena pertumbuhan diameter sejalan dengan peningkatan kandungan karbon pada vegetasi mangrove. Pernyataan tersebut sejalan dengan pendapat Hariah dan Rahayu (2007) yang menyatakan besarnya diameter yang dipengaruhi oleh usia pohon akan berdampak pada peningkatan biomassa termasuk karbon. 
Pengaruh jenis berdasarkan uji statistik menunjukkan hasil bahwa jenis tidak berpengaruh signifkan terhadap kandungan karbon atas permukaan tanah pada hutan alam Tahura Ngurah Rai. Pada hutan alam Tahura Ngurah Rai, jenis yang dominan adalah Sonneratia alba. Kandungan karbon atas ratarata per hektar pada hutan alam Tahura Ngurah Rai yang didominasi oleh Sonneratia alba sebesar 90,03 ton/ha lebih besar dari penelitian yang dilakukan oleh Putra et al. (2019) yang menyatakan bahwa kemampuan mangrove jenis Sonneratia alba dalam menyimpan karbon diperkirakan sebesar 15,71 ton/ha. Namun lebih kecil apabila dibandingkan dengan penelitian Syukri et al. (2018) yang menyatakan kandungan karbon per hektar jenis Sonneratia alba berkisar antara 196.39 - 293.9 ton/ha.

Tabel 6. Output Coefficients Hubungan Diameter dan Jenis Pohon terhadap Simpanan Karbon Atas di Hutan Alam Tahura Ngurah Rai

Coefficients $^{\mathrm{a}}$

\begin{tabular}{|c|c|c|c|c|c|c|}
\hline & \multirow[b]{2}{*}{ Model. } & \multicolumn{2}{|c|}{ Unstandardized.Coefficients } & \multirow{2}{*}{$\begin{array}{c}\begin{array}{c}\text { Standardized. } \\
\text { Coefficients }\end{array} \\
\text { Beta. }\end{array}$} & \multirow[b]{2}{*}{ t. } & \multirow[b]{2}{*}{ Sig. . } \\
\hline & & B. & Std. Error. & & & \\
\hline \multirow[t]{3}{*}{1.} & (Constant) . & 9.942 & 78.810 & & .126 & .902 \\
\hline & Rata-rata Diameter & 6.787 & 4.785 & .393 & 1.418 & .181 \\
\hline & Jenis Dominan & -34.112 & 25.708 & -.368 & -1.327 & .209 \\
\hline
\end{tabular}

a. Dependent Variable: Kandungan karbon Atas

\subsection{Hubungan antara Ukuran Diameter dan Jenis Pohon dengan Kandungan Karbon Atas di Hutan Rehabilitasi}

Untuk mengetahui apakah diameter dan jenis pohon berpengaruh terhadap simpanan karbon atas pada hutan rehabilitasi Tahura Ngurah Rai, dilakukan analisis terhadap output uji statistik seperti pada Tabel 7.

Berdasarkan Tabel 7., diperoleh nilai signifikansi untuk rata-rata diameter sebesar 0,186 atau lebih tinggi (>) 0,05 sehingga diameter tidak berpengaruh nyata pada kandungan karbon atas permukaan tanah di hutan rehabilitasi Tahura Ngurah Rai. Untuk nilai signifikansi jenis dominan sebesar 0,759 atau lebih tinggi (>) 0,05 bermakna bahwa jenis pohon juga tidak berpengaruh nyata pada kandungan karbon atas di hutan rehabilitasi Tahura Ngurah Rai.

Karena 2 (dua) variabel bebas yang diuji terhadap simpanan karbon atas di hutan rehabilitasi tidak memberikan pengaruh nyata, maka persamaan regresi linear diabaikan. Adinugroho dan Sidiyasa (2006) menyatakan bahwa terdapat hubungan erat antara dimensi pohon (diameter dan tinggi) dengan biomassa dan kandungan karbon. Hairiah dan Rahayu
(2007) menyatakan ukuran diameter batang berbanding lurus dengan nilai biomassa, semakin tinggi DBH (Diameter at Breast Height) maka mengindikasikan semakin tua pohon tersebut dan mempunyai cadangan karbon yang lebih banyak. Sejalan dengan pendapat tersebut, Maulana (2009) menyatakan tingginya potensi kandungan karbon lebih dipengaruhi oleh komposisi diameter dan berat jenis pohon daripada kerapatan tutupan lahan. Hikmatyar et al. (2015) juga menyatakan bahwa diameter batang, kerapatan individu, keragaman jenis pohon merupakan parameter yang mempengaruhi biomassa dan kandungan karbon pada suatu ekosistem.

Pengaruh jenis berdasarkan uji statistik menunjukkan hasil bahwa jenis tidak berpengaruh signifkan terhadap kandungan karbon atas permukaan tanah pada hutan rehabilitasi Tahura Ngurah Rai. Pada hutan rehabilitasi Tahura Ngurah Rai, jenis yang dominan dan awalnya diduga berpengaruh signifikan terhadap kandungan karbon atas mangrove adalah jenis Rhizophora stylosa. Kandungan karbon atas rata-rata per hektar pada hutan rehabilitasi Tahura Ngurah Rai 
yang didominasi oleh Rhizophora stylosa sebesar 75,75 ton $\mathrm{C} / \mathrm{ha}$. Walaupun tidak berpengaruh nyata secara statistik, kandungan karbon Rhizophora stylosa lebih besar dibandingkan jenis yang lain. Hal ini sesuai penelitian Suryono et al. (2018) bahwa biomassa dan cadangan karbon dari Rhizophora sp. lebih tinggi dibandingkan dengan jenis lainya. Kareninsekar (2020) juga menyatakan bahwa Rhizophora stylosa memiliki kemampuan menyerap karbon tertinggi dibandingkan dengan jenis Avicennia marina dan Bruguierra gymnorrhiza, dimana kemampuan serapan tertinggi terutama pada bagian batang.

Tabel 7. Output Coefficients Hubungan Diameter dan Jenis Pohon terhadap Kandungan Karbon Atas Permukaan Tanah pada Hutan Rehabilitasi Tahura Ngurah Rai

Coefficients $^{a}$

\begin{tabular}{|c|c|c|c|c|c|c|}
\hline \multirow{2}{*}{\multicolumn{2}{|c|}{ Model. }} & \multicolumn{2}{|c|}{ Unstandardize.Coefficients } & \multirow{2}{*}{$\begin{array}{c}\begin{array}{c}\text { Standardized. } \\
\text { Coefficients }\end{array} \\
\text {.Beta. }\end{array}$} & \multirow[b]{2}{*}{ t. } & \multirow[b]{2}{*}{.Sig. . } \\
\hline & & .B. & .Std. Error. & & & \\
\hline \multirow[t]{3}{*}{1.} & (Constant) . & -30.382 & 79.493 & & -.382 & .709 \\
\hline & Rata-rata Diameter & 12.002 & 8.558 & .420 & 1.402 & .186 \\
\hline & Jenis Dominan & 14.532 & 46.204 & .094 & .315 & .759 \\
\hline
\end{tabular}

a. Dependent Variable: Kandungan karbon Atas

\section{SIMPULAN DAN SARAN}

\subsection{Simpulan}

1) Kandungan karbon atas permukaan tanah per ha pada hutan alam Tahura Ngurah Rai sebesar 90,03 ton/ha tidak berbeda nyata dengan kandungan karbon per hektar pada hutan rehabiltasi sebesar 75,75 ton/ha. Hal ini berarti bahwa pertumbuhan vegetasi pada hutan rehabilitasi sudah hampir sama dengan pertumbuhan vegetasi pada hutan alam.

2) Ukuran diameter dan jenis mangrove tidak berpengaruh nyata pada kandungan karbon atas di hutan alam dan hutan rehabilitasi pada taraf signifikan 5\%.

\subsection{Saran}

1) Untuk menjaga fungsi mangrove sebagai penyerap karbon perlu mempertahankan kelestarian mangrove dan melakukan rehabilitasi pada kawasan yang rusak.

2) Upaya rehabilitasi mangrove harus memperhatikan kesesuaian jenis mangrove dengan karakteristik lapangan sehingga akan meningkatkan persentase keberhasilan kegiatan rehabilitasi yang akan berdampak pada peningkatan cadangan karbon.

\section{DAFTAR PUSTAKA}

Adinugroho, C. W. dan Sidiyasa, K. 2001. Model Pendugaan Biomassa Pohon Ma honi (Swietenia macrophylla King) di atas Permukaan Tanah.

Jurnal penelitian Hutan dan

Konservasi Alam, III (1) : 103 - 117.

Arief, A. 2001. Hutan dan Kehutanan. Yogyakarta: Kanisius.

Asy'ari, M., dan Karim, A.A. 2012. Pengukuran Kayu,

Fakultas Kehutanan, Universitas

Lambung Mangkurat, Banjarbaru.

Bachmid, F., Sondak, C.F.A., Kusen, J.D. 2018

Estimasi Penyerapan Karbon Hutan

Mangrove Bahowo Kelurahan Tongkai na Kecamatan Bunaken. Jurnal Pesisir dan Laut Tropis. Vol. 1 (1):8-13

Badan Standarisasi Nasional. 2011. Pengukuran dan penghitungan cadangan karbon

Pengukuran lapangan untuk penaksiran 
cadangan karbon hutan (ground based forest carbon accounting). Jakarta.

Hairiah, K., Rahayu, S. 2007. Pengukuran Karbon Tersimpan di Berba gai Macam Penggunaan Lahan. World Agroforestry Centre. ICRAF, SEA Regional Office, University of Brawijaya, Indonesia.

Handoko,

E. 2016. Analisis Biomassa dan Cadangan Karbo n pada Ekosistem Hutan Mangrove di Kawasan Pesisir Selatan Pulau Rupat Provinsi Riau. Skripsi pada Jurusan Ilmu Kelautan Fakultas Perikanan dan Kelaut an Universitas Riau, Pekanbaru.

IPCC. 2006.

IPCC Guidelines for National Greenho use Gas Inventories, Prepared by the National Greenhouse Gas Inventories Pr ogramme, Eggleston H.S., Buendia L., Miwa K., Ngara T. and Tanabe K. (eds). Japan: IGES.

Komiyama, A., Poungpam, S. \& Karto, S. 2005.

Common Allometric Equations for

Estimating The Tree Weight of

Mangroves.

Journal of Tropical Ecology. 21(4).

Massugito. 2016. "Analisis Cadangan Karbon pada Ekosistem Hutan Mangrove di Kawasan Pesisir Kuala Indragiri Provinsi Riau". (Skripsi). Jurusan Ilmu Kelautan Fakultas Perikanan dan Kelautan. Universitas Riau, Pekanbaru.

Oktaviona, S., Amin, B., Ghalib, M. 2017. Estimasi Stok Karbon Tersimpan pada Ekosistem Hutan mangrove di Jorong Ujuang Labuang Kabupaten Agam Provinsi Sumatera Barat. Postal
Address: Kampus Bina Widya Sp. Panam Pekanbaru-Riau-Indonesia.

Pratama, I.G.M.Y., Karang, I.W.G.A., Suteja, Y. 2019. Distribusi Spasial Kerapatan Mangrove Menggunakan Citra Sentinel2A Di TAHURA Ngurah Rai Bali. Journal of Marine and Aquatic Sciences 5(2), 192-202.

Putra, A.A., Rudianto, Dewi, C.S.U. 2019. Analisis Kemampuan Sekuestrasi dan Penyimpanan Karbon Hutan Mangrove di Desa Pejarakan, Kabupaten Buleleng, Bali. Jurnal Ilmu dan Teknologi Kelautan Tropis. Vol. 11 No.3: 511-526.

Sofyan, M. 2016. "Analisis Biomassa dan Cadangan Karbon pada Ekosistem Hutan Mangrove di Kawasan Pesisir Rupat Utara Provinsi Riau”. (Skripsi). Jurusan Ilmu Kelautan Fakultas Perikanan dan Kelautan. Universitas Riau, Pekanbaru.

Suryono., Soenardjo, N., Wibowo, E., Ario, R., \& Rozy, E.F. 2018. Estimasi Kandungan Biomassa dan Karbon di Hutan Mangrove Perancak Kabupaten Jembrana Provinsi Bali. Bul. Oseano. Mar. 7(1):1-8.

Syukri, M., Mashoreng, S., Werorilangi, S., Isyrini, R., Rastina, Faizal, A., Tahir, A. 2018. Kajian Stok Karbon Mangrove di Bebanga Kabupaten Mamuju Sulawesi Barat. Prosiding Simposium Nasional Kelautan dan Perikanan V Universitas Hasanuddin, Makassar.

Widyantari, I. A. D. 2013. "Potensi Simpanan Karbon di Kawasan Rehabilitasi Mangrove Taman Hutan Raya Ngurah Rai, Bali”. (Skripsi). Jurusan Konservasi Sumber Daya Hutan. Universitas Gajah Mada. 